\title{
Dietary Interventions for Treatment of Chronic Pain: Oxidative Stress and Inflammation
}

\author{
Ashish S. Kaushik · Larissa J. Strath · Robert E. Sorge
}

Received: August 13, 2020 / Accepted: September 22, 2020 / Published online: October 21, 2020

(C) The Author(s) 2020

\section{ABSTRACT}

Chronic pain is highly prevalent in the United States, impacting $28.4 \%$ of the adult population, or 69.6 million people, as of 2016. Chronic pain is often associated with anxiety, depression, and restrictions in mobility and daily activities, substantially reducing quality of life. Analgesics, especially opioids, are one of the primary pharmaceutical treatment methods for chronic pain. However, prescription opioid misuse and abuse has become increasingly prevalent and concerning, prompting the need for research into alternative treatment methods which avoid the side effects of traditional treatments. Chronic pain is, in part, thought to be the result of oxidative stress and inflammation, and clinical research has indicated links between these conditions and diet. Thus, dietary interventions are a particularly promising therapeutic treatment for chronic pain, with numerous studies suggesting that diet has a noticeable effect on pain as far down as the cellular level. In this review article, data from a number of clinical trials assessing the effect of three diets-antioxidant-rich, low-carbohydrate, and Mediterranean-on oxidative stress and inflammation is compiled and discussed in

A. S. Kaushik · L. J. Strath · R. E. Sorge ( $₫)$

Department of Psychology, University of Alabama at

Birmingham, Birmingham, AL, USA

e-mail: rsorge@uab.edu the context of chronic pain. Clinical data suggests that low-carbohydrate diets and Mediterranean diets both are especially promising dietary interventions.

Keywords: Chronic pain; Diet; Inflammation; Intervention; Low-carbohydrate; Mediterranean diet; Oxidative stress

\section{Key Summary Points}

Oxidative stress may play a role in chronic pain.

Diet influences oxidative stress and inflammation.

Low-carbohydrate diets may be beneficial for chronic pain via reductions in oxidative stress.

Mediterranean diets have shown promise for reducing pain and inflammation.

Diets may be beneficial alternatives or adjuncts for chronic pain management. 


\section{DIGITAL FEATURES}

This article is published with digital features to facilitate understanding of the article. To view digital features for this article go to https://doi. org/10.6084/m9.figshare.12982187.

\section{INTRODUCTION}

Chronic pain is highly prevalent in the United States and affects $28.4 \%$ of the adult population, or 69.6 million people, as of 2016 [1]. This condition is often associated with anxiety, depression, and restrictions in mobility and daily activities, substantially reducing quality of life. Analgesics are the primary pharmaceutical treatment method for chronic pain, especially opioids [2]. However, prescription opioid misuse and abuse has become increasingly prevalent and concerning, and the side effects of these drugs can also contribute to substantial declines in health and quality of life [2, 3]. There is a growing need for research into alternative treatment methods that avoid the side effects of traditional treatments [2]. Dietary interventions are one such form of treatment, with numerous studies suggesting that diet has a noticeable effect on pain [4-20]. These effects may be due to the influences diet has on oxidative stress and inflammation, which are the widely hypothesized mechanisms for chronic pain. Inflammation is present in a number of painful conditions [21-28] and reduction of inflammation is often related to a decrease in pain $[15,29-31]$. It is known that oxidative stress can contribute to inflammation $[32,33]$, so it is reasonable that both oxidative stress and inflammation may underlie chronic painful conditions.

In this review, a number of clinical trials of dietary interventions will be examined to assess whether clinical implementation of diet has a significant influence on oxidative stress, inflammation, or pain symptoms in order to assess the potential for diet as a therapeutic treatment for chronic pain. The intention of this narrative review is to summarize the clinical trials that have shown promise as a means to reduce oxidative stress and experienced pain in patients with chronic pain conditions. This review is based on previously conducted studies and does not contain any studies with human participants or animals performed by any of the authors.

\section{OXIDATIVE STRESS AND PAIN}

Oxidative stress occurs when free radical compounds such as reactive oxygen species (ROS) or reactive nitrogen species (RNS) are imbalanced with antioxidant defense systems in the body [34-36]. When certain macronutrients are consumed in excess and are broken down, natural oxidative by-products of their metabolism triggers oxidative stress responses and production of more ROS when bound to their receptors more so than the body is equipped to handle. Excessively high levels of free radicals cause damage to essential protein, lipid, and nucleic acid components of cells, eventually leading to damage and apoptosis [37]. Under normal conditions, ROS are produced as a byproduct of metabolism of molecular oxygen [38, 39], and serve important roles in signaling pathways and responses to changes of environmental conditions [38-41]. Furthermore, under normal conditions, the antioxidant defense system neutralizes excess free radicals to prevent damage [42-44]. While oxidative stress has been associated to painful conditions [26, 45-48], the direct link is not yet understood. It is hypothesized that oxidative stress contributes to pain by exacerbating pathological responses like inflammation and neuropathy, which both contribute to pain.

\section{OXIDATIVE STRESS AND INFLAMMATION}

Inflammation occurs when immune cells respond to a multitude of biochemical and physical influences, including infection, allergens, injury, radiation, and diet-induced oxidative stress $[49,50]$. Inflammation as a whole involves the release of cytokines and chemokines from immune cells that can result in sensitivity as a function of the natural 
healing processes. However, prolonged inflammation can result in chronic hypersensitivity and may be related to chronic pain. Chronic inflammation can produce a number of symptoms, particularly chronic pain [22, 23, 49]. During the immune response, increased oxygen consumption by immune cells such as mast cells and leukocytes causes the release and accumulation of ROS. This initiates a cycle in which pro-inflammatory mediators like cytokines and chemokines are produced, all of which activate and recruit additional inflammatory immune cells which, in turn, release additional ROS [51]. A number of influences on oxidative stress-induced inflammation have been identified, including transcription factors, chemokines, inflammatory cytokines, and microRNAs. In addition to promoting release of reactive species, these compounds can stimulate nociceptors and afferent pain neurons, thereby contributing to chronic pain [52].

\section{DIETARY INFLUENCES ON OXIDATIVE STRESS AND INFLAMMATION}

While oxidative stress can result from a number of physical and biochemical processes including UV radiation, smoking, and air pollution, studies have identified a number of dietary influences on oxidative stress. Nutritional stress has been shown to both increase free radicals and hinder the antioxidant defense system, thereby creating an imbalance in the local environment leading to oxidative stress [53]. Diets like the standard American diet (SAD), characterized by elevated intake of processed carbohydrates and saturated fats [54, 55], have been linked to increased postprandial oxidative stress in the short term and chronic elevation of oxidative stress markers in the long term [56-60].

Carbohydrates in particular have been identified as key source of oxidative stress, specifically through glucose oxidation [37]. In this process, glucose is oxidized into a superoxide anion radical species, which causes production of ROS and RNS if not properly degraded by the antioxidant defense system [61-66].
Furthermore, excess carbohydrates promote lipid peroxidation of low-density lipoprotein (LDL) cholesterol through superoxide-dependent pathways, causing additional production of free radicals [67, 68]. Excess carbohydrates allow for glycation reactions to occur between excess carbohydrates and other nutrients like lipids, proteins, and nucleic acids, producing advanced glycation end products (AGEs) [69-74].

\section{DIETARY ANTIOXIDANTS}

Oxidative stress may be the underlying mechanism for a variety of pain-related symptoms, and it occurs when there are too many free radical species to be managed by the body's innate antioxidant defense system. Thus, supplementation with dietary antioxidants intuitively arises as a potential treatment method. Dietary antioxidants can be found in a wide variety of over-the-counter vitamins and supplements, and they can also be obtained in whole foods such as berries, fruits, nuts, chocolate, vegetables, and green tea [75]. However, the research currently available is inconclusive as to whether antioxidants obtained through diet are metabolized in a way which supplements the body's innate antioxidant defense system and thereby minimizes oxidative stress. Likewise, clinical trials examining the effects of dietary antioxidants and inflammatory markers are also inconclusive.

A number of in vitro studies suggest that dietary antioxidants like vitamin $\mathrm{C}$, vitamin $\mathrm{E}$, beta-carotene, and flavonoids can reduce oxidative stress in biological systems [76-79]. For example, vitamin $\mathrm{C}$ has been shown to minimize oxidative stress damage to lipid and protein-based cellular components, and vitamin $\mathrm{E}$ has been shown to prevent lipid peroxidation $[76,78,79]$. In a randomized controlled trial, adherence to a polyphenol-rich diet significantly reduced levels of the oxidative stress biomarker urinary-8-isoprostane, indicating a link between dietary polyphenol supplementation and improvements in oxidative stress in humans [80]. However, a number of other clinical trials performed indicate that 
consumption of these same antioxidants and others does not yield the same results demonstrated via in vitro testing [79]. Current clinical evidence suggests that oxidative biomarkers are lowered by antioxidant supplementation for individuals with above-baseline oxidative stress levels, but antioxidant supplementation does not have significant impact on individuals with normal levels of oxidative stress [79].

Clinical research on the impact of dietary antioxidants on inflammation are also inconclusive. In a controlled, randomized clinical trial, participants were given antioxidant pills containing carotenoids, mixed tocopherols, vitamin $C$, and selenium to double their antioxidant levels as verified by diet records and blood concentrations [81]. Three inflammatory markers (interleukin-6, IL-6; monocyte chemotactic protein-1, MCP-1; soluble intercellular adhesion molecule-1, sICAM-1) were analyzed, and despite increased antioxidant levels, no significant changes were observed for any of the inflammatory markers over the 8-week period [81].

Even still, there still is evidence that dietary antioxidants may have an effect on pain, even if not through the inflammation pathway. A 2019 study performed on individuals with knee osteoarthritis showed that over a 4-month period, participants who consumed $40 \mathrm{~g}$ of freezedried blueberry powder daily exhibited less pain, stiffness, and had less difficulty performing daily activities when compared to participants consuming a placebo [7]. However, no significant changes were found in inflammatory biomarkers, indicating that, while an effect on pain may be observable, antioxidant supplementation may have a greater effect on minimizing oxidative stress than inflammation. However, oxidative stress markers were not examined in that study.

There are a number of limitations to investigation of dietary antioxidants in clinical trials which may influence their perceived efficacy. For one, dietary antioxidants are typically implemented in the clinical setting as secondary prevention methods, meaning they are implemented after oxidative stress has already caused progression of the disease state, at which point cellular damage has surpassed the antioxidant defense system's capabilities. Furthermore, the exact mechanisms of many antioxidants and their relation to specific diseases (such as chronic pain) are unknown, thereby complicating whether failure of a particular dietary antioxidant for a condition can conclusively rule out all dietary antioxidants [79].

\section{LOW-CARBOHYDRATE DIETS}

Given the substantial impact carbohydrates have on producing oxidative stress, research has pointed to low-carbohydrate diets as means to reduce oxidative stress and potentially aid with chronic pain. While clinical data on implementation of these diets is limited given their recent attention, some clinical studies have been performed with positive results. In a randomized, controlled trial in groups administered either a hypocaloric high-protein diet (low calorie, high protein and low carbohydrate) or a hypocaloric high-carbohydrate diet (low calorie and high carbohydrate) over a 6-month period, participants in the high protein/lower carbohydrate group demonstrated a greater decrease in both oxidative stress and inflammatory markers [82]. While pain itself was not measured in this study, oxidative stress and inflammation are the theoretical underlying mechanisms for pain; however, more recent clinical studies have shown a more direct association between decreases in these biomarkers and decreased pain perception. In a randomized, controlled trial of 21 study participants diagnosed with knee osteoarthritis, study participants were assigned to either a low-carbohydrate diet (LCD), a low-fat diet (LFD), or their own diet over a period of 12 weeks. Participants in the LCD group showed reduced task-related pain, reduced self-reported pain, and lower oxidative stress blood serum biomarkers when compared to LFD and control group participants. However, the study noted a number of factors that may influence results that were not tested due to the low sample size, including race/ethnicity differences and sex differences [19]. Importantly though, these findings demonstrate the potential of a low- 
carbohydrate diet as a therapeutic treatment for pain, as well as for other pain disorders associated with increased oxidative stress.

\section{MEDITERRANEAN DIET}

The Mediterranean diet has received attention due to positive experimental results with respect to cardiovascular disease and other conditions [83, 84]. While clinical studies vary in their implementation of the Mediterranean diet, the diet is generally defined by daily consumptions of fruits, vegetables, whole grains, and healthy fats, especially monounsaturated fatty acids (MUFAs) from virgin olive oil. Furthermore, the Mediterranean diet entails limited intake of red meat and dairy, with a focus on fish, poultry, beans, and eggs as the primary sources of protein [85]. While many of these characteristics contrast with the standard American diet, one key difference is in fat consumption. According to the 2015-2020 "Dietary Guidelines for Americans," the recommendation for saturated fat consumption was $10 \%$ of total energy intake. However, saturated fats account for around $19 \%$ of the average American's energy intake, while in the Mediterranean diet, saturated fats account for just $9 \%$, with a greater emphasis on MUFA consumption $[85,86]$. It is worth noting that the traditional version of the Mediterranean diet is naturally low in processed carbohydrates and may be considered a version of a low-carbohydrate diet.

In a 2014 study conducted among adults with elevated risk for cardiovascular disease, study participants were given a Mediterranean diet supplemented with either extra virgin olive oil or nuts for a 12-month period. When compared a low-fat diet group, the participants given the Mediterranean diet exhibited a significant reduction of inflammatory biomarkers C-reactive protein and IL-6. Interestingly, when comparing the two intervention groups, those given nuts showed more than double the reduction of inflammatory biomarkers [87]. Another study focusing on the effects of olive oil polyphenols in the Mediterranean diet assigned study participants a Mediterranean diet using virgin olive oil or washed olive oil, which has a lower polyphenol count. When compared to the control group, both groups showed decreased plasma oxidative stress and inflammatory biomarkers \{Konstantinidou, 2010 \#5158\}. Furthermore, gene expression was also examined in the context of atherosclerosisrelated genes, which identified the key role of polyphenols in the down-regulation of proatherogenic genes, which normally contribute to arterial plaques [88]. These findings indicate that olive oil consumption in the Mediterranean diet may be an important factor in reduction of oxidative stress and inflammation. Furthermore, the identification of a link between olive oil polyphenols, a dietary antioxidant, and genetic changes may be an important precedent for studies examining oxidative stress and chronic pain-related genes.

\section{DISCUSSION}

The available data supports the notion that the most promising diets for addressing chronic pain through the oxidative stress and inflammation pathways are the low-carbohydrate diet and Mediterranean diet (Table 1). Dietary antioxidants appear to play a potential role in reduction of chronic pain; however, clinical data is less conclusive. Unfortunately, none of the diets studied are particularly well researched in the context of chronic pain with an emphasis on oxidative stress, and future studies will be required before clinicians should consider prescribing a diet as treatment for pain.

A number of limitations are present which influence the strength of the conclusions. First, results were limited due to the small number of clinical studies examining diet and oxidative stress/inflammation. This scarcity could be due to a number of factors, such as the novelty of the treatment method, but one key factor hindering the prevalence of clinical studies is that diet studies are particularly challenging due to the significant change in lifestyle required of patients. This key element makes diet interventions a less appealing treatment for most diseases over pharmaceutical treatments, even when medications have negative side effects. However, a strong case can be made that dietary 
Table 1 Compilation of dietary clinical trials and outcomes

\begin{tabular}{|c|c|c|c|c|c|}
\hline Diet & Study Population & Location & Duration & Primary Outcome & Reference \\
\hline Low-carbohydrate & $\begin{array}{l}\text { Adults with knee } \\
\text { osteoarthritis }\end{array}$ & USA & $\begin{array}{l}12 \\
\text { weeks }\end{array}$ & $\begin{array}{l}\text { Reduced evoked pain, } \\
\text { reduced TBARS (oxidative } \\
\text { stress) }\end{array}$ & [19] \\
\hline Low-carbohydrate & $\begin{array}{l}\text { Obese, } \\
\text { premenopausal } \\
\text { women }\end{array}$ & USA & $\begin{array}{l}6 \\
\text { months }\end{array}$ & $\begin{array}{l}\text { Reduced markers of } \\
\text { oxidative stress and } \\
\text { inflammatory cytokines }\end{array}$ & [83] \\
\hline $\begin{array}{l}\text { Antioxidant } \\
\text { (polyphenols) }\end{array}$ & $\begin{array}{l}\text { Overweight/obese } \\
\text { adults }\end{array}$ & Italy & 8 weeks & $\begin{array}{l}\text { Reduced urinary-8- } \\
\text { isoprostane levels } \\
\text { (oxidative stress) }\end{array}$ & [80] \\
\hline $\begin{array}{l}\text { Antioxidant } \\
\text { (carotenoids, } \\
\text { tocopherols, vitamin } \\
\text { C, selenium) }\end{array}$ & $\begin{array}{l}\text { Adults with elevated } \\
\text { risk for cardiovascular } \\
\text { disease }\end{array}$ & USA & 8 weeks & $\begin{array}{l}\text { No significant changes in } \\
\text { inflammatory markers } \\
\text { (IL-6, MCP-1, sICAM-1) }\end{array}$ & [81] \\
\hline $\begin{array}{l}\text { Antioxidant (Whole } \\
\text { blueberries) }\end{array}$ & $\begin{array}{l}\text { Adults with } \\
\text { symptomatic knee } \\
\text { osteoarthritis }\end{array}$ & USA & $\begin{array}{l}4 \\
\text { months }\end{array}$ & $\begin{array}{l}\text { Reduced pain, stiffness, } \\
\text { and movement } \\
\text { difficulties, improved } \\
\text { gait, no significant } \\
\text { changes in inflammatory } \\
\text { markers }\end{array}$ & [82] \\
\hline High-fat (saturated) & $\begin{array}{l}\text { Adults with metabolic } \\
\text { syndrome }\end{array}$ & USA & 8 hours & $\begin{array}{l}\text { Increased postprandial } \\
\text { TBARS (oxidative stress), } \\
\text { increased IL-1 } \beta \\
\text { (inflammation) }\end{array}$ & [59] \\
\hline $\begin{array}{l}\text { Mediterranean Diet: } \\
\text { High unsaturated fat } \\
\text { via Virgin Olive Oil } \\
\text { (VOO) \& Nuts vs low- } \\
\text { fat }\end{array}$ & $\begin{array}{l}\text { Adults with elevated } \\
\text { risk for cardiovascular } \\
\text { disease }\end{array}$ & Spain & $\begin{array}{l}12 \\
\text { months }\end{array}$ & $\begin{array}{l}\text { Reduced IL-6 and sICAM } \\
\text { (inflammatory markers) } \\
\text { in MD groups }\end{array}$ & [88] \\
\hline $\begin{array}{l}\text { Mediterranean Diet } \\
\text { (MD): High } \\
\text { unsaturated fat via } \\
\text { Virgin Olive Oil (VOO) } \\
\text { polyphenols }\end{array}$ & Healthy adults & Spain & $\begin{array}{l}3 \\
\text { months }\end{array}$ & $\begin{array}{l}\text { Reduced plasma } \\
\text { oxidative stress and } \\
\text { inflammatory markers in } \\
\text { MD+VOO (retained } \\
\text { polyphenols) group }\end{array}$ & [90] \\
\hline
\end{tabular}

Outcomes are color coded by overall effect, with green representing a positive effect, red representing a negative effect, and yellow representing no significant overall effect 
interventions primarily have positive side effects. Thus, when deciding between treatments, both clinicians and patients should consider the costs and benefits of both pharmacotherapy and diet interventions. In fact, it may be the case that the two can be used in conjunction with the hope of tapering medication as the positive benefits of the diets are experienced.

Furthermore, within the few available studies examining the influence of diet on oxidative stress and inflammation, only two were specifically conducted in the context of chronic pain and measured pain of participants [7, 19]. While there is evidence to suggest the link between the oxidative stress/inflammation pathways and chronic pain, other potential factors beyond oxidative stress and inflammation may play important roles. Unless a study directly measures participants' perceived and evoked pain, there is a level of skepticism that must be maintained about the study's impact on chronic pain.

Inherent in clinical trials of diet interventions in this area are inconsistencies in diet characteristics make comparisons from study to study challenging. There are no standardized clinical research definitions for the exact specifications of a low-carbohydrate or Mediterranean diet; rather, exact implementation of a particular diet is subject to researchers' interpretations. Additionally, some interventions may focus on one macronutrient category (i.e., fats) and, in order to maintain an isocaloric diet, the other macronutrients have less rigor applied from day-to-day. Thus, a study may examine a low-fat diet, but some participants could increase their carbohydrate consumption while others increase proteins. Overall, the group as a whole reduced their fat intake, but the other aspects of the diet were dramatically different, possibly leading to variability in results.

A significant for the implementation of a dietary intervention is the substantial impact that one's socioeconomic status, environment, and culture have on diet and ability to access various foods. Chronic pain disproportionately affects minority groups [90] with typically lower socioeconomic status (SES) [91]. Similarly, epidemiological studies have shown that social class and resulting SES predict the quality of a person's diet with higher SES being associated with healthier diets [92]. Over multiple studies comparing the Mediterranean diet to the Western diet, the Mediterranean diet is more expensive and the cost is positively related to adherence $[93,94]$. It should be noted that one systematic review compared the cost of the Mediterranean diet to the average healthcare costs for a number of conditions between those adhering to the diet and those who did not. The researchers found that adoption of the Mediterranean diet increased quality of life and may extend lifespan to a moderate degree for those with various medical conditions [95]. Thus, the long-term gain in health and quality of life may supersede the short-term increase in cost.

Unfortunately, carbohydrates are typically the least expensive component of the standard American diet. Therefore, prescribing a lowcarbohydrate diet is likely to increase daily food costs and is worth careful consideration, especially for those with lower SES. Furthermore, diet plays an especially important role in one's identity and culture. Thus, in prescribing a diet such as a low-carbohydrate diet, key cultural components of the standard diet should be identified and substitutes recommended to maintain the basics of the diet. For example, patients from cultures with high rice consumption could be advised to consider a lowercarbohydrate option such as "riced" cauliflower, which can be inexpensive satisfying cost-related issues.

\section{CONCLUSIONS}

Out of the diets identified to have clinical evidence supporting their potential to reduce oxidative stress, inflammation, and/or chronic pain, the most promising diets are the low-carbohydrate diet and the Mediterranean diet. Dietary antioxidant supplementation also appears to have an impact, but studies have had conflicting results. Added to that are the individual differences in absorption of vitamins and minerals between sexes [96] and across racial groups [97]. It is a possibility that diet 
interventions will need to be tailored to patients based on conditions, sex, and race/culture. More research is needed to examine the ways that diets impact pain, inflammation and chronic pain, but the limited results are promising. With a sensitivity to SES and culture, diet interventions may be alternative or complimentary strategies for chronic pain that have the potential to promote health and extend lifespan.

\section{ACKNOWLEDGEMENTS}

Funding. No funding or sponsorship was received for this study or publication of this article.

Authorship. All named authors meet the International Committee of Medical Journal Editors (ICMJE) criteria for authorship for this article, take responsibility for the integrity of the work as a whole, and have given their approval for this version to be published.

Authorship Contributions. Ashish Kaushik wrote the manuscript. Larissa J. Strath and Robert E. Sorge edited and provided feedback during the writing of the manuscript.

Disclosures. Ashish Kaushik, Larissa J. Strath and Robert E. Sorge have nothing to disclose.

Compliance with Ethics Guidelines. This article is based on previously conducted studies and does not contain any studies with human participants or animals performed by any of the authors.

Open Access. This article is licensed under a Creative Commons Attribution-NonCommercial 4.0 International License, which permits any non-commercial use, sharing, adaptation, distribution and reproduction in any medium or format, as long as you give appropriate credit to the original author(s) and the source, provide a link to the Creative Commons licence, and indicate if changes were made. The images or other third party material in this article are included in the article's Creative Commons licence, unless indicated otherwise in a credit line to the material. If material is not included in the article's Creative Commons licence and your intended use is not permitted by statutory regulation or exceeds the permitted use, you will need to obtain permission directly from the copyright holder. To view a copy of this licence, visit http://creativecommons.org/licenses/by$\mathrm{nc} / 4.0 /$.

\section{REFERENCES}

1. Dahlhamer J, Lucas J, Zelaya C, Nahin R, Mackey S, DeBar L, et al. Prevalence of chronic pain and highimpact chronic pain among adults-United States, 2016. MMWR Morb Mortal Wkly Rep. 2018;67(36): 1001-6.

2. Kaye AD, Jones MR, Kaye AM, Ripoll JG, Galan V, Beakley BD, et al. Prescription opioid abuse in chronic pain: an updated review of opioid abuse predictors and strategies to curb opioid abuse: part 1. Pain Phys. 2017;20(2s):S93-s109.

3. Han B, Compton WM, Blanco C, Crane E, Lee J, Jones CM. Prescription opioid use, misuse, and use disorders in us adults: 2015 national survey on drug use and health. Ann Intern Med. 2017;167(5): 293-301.

4. Allison DJ, Ditor DS. Maintenance of diet participation in individuals with spinal cord injury: effect on mood and neuropathic pain. Spinal Cord Ser Cases. 2018;4:97.

5. Bliddal H, Leeds AR, Stigsgaard L, Astrup A, Christensen R. Weight loss as treatment for knee osteoarthritis symptoms in obese patients: 1-year results from a randomised controlled trial. Ann Rheum Dis. 2011;70(10):1798-803.

6. Correa-Rodriguez M, Casas-Barragan A, GonzalezJimenez E, Schmidt-RioValle J, Molina F, AguilarFerrandiz ME. Dietary inflammatory index scores are associated with pressure pain hypersensitivity in women with fibromyalgia. Pain Med. 2020;21(3): 586-94.

7. Du C, Smith A, Avalos M, South S, Crabtree K, Wang $\mathrm{W}$, et al. Blueberries improve pain, gait performance, and inflammation in individuals with symptomatic knee osteoarthritis. Nutrients. 2019;11(2):290. 
8. Emery CF, Olson KL, Bodine A, Lee V, Habash DL. Dietary intake mediates the relationship of body fat to pain. Pain. 2017;158(2):273-7.

9. Hagen KB, Byfuglien MG, Falzon L, Olsen SU, Smedslund G. Dietary interventions for rheumatoid arthritis. Cochrane database Syst Rev. 2009;1: CD006400.

10. Herati AS, Shorter B, Srinivasan AK, Tai J, Seideman C, Lesser M, et al. Effects of foods and beverages on the symptoms of chronic prostatitis/chronic pelvic pain syndrome. Urology. 2013;82(6):1376-80.

11. Kaartinen K, Lammi K, Hypen M, Nenonen M, Hanninen O, Rauma AL. Vegan diet alleviates fibromyalgia symptoms. Scand J Rheumatol. 2000;29(5):308-13.

12. Marum AP, Moreira C, Saraiva F, Tomas-Carus P, Sousa-Guerreiro C. A low fermentable oligo-dimono saccharides and polyols (FODMAP) diet reduced pain and improved daily life in fibromyalgia patients. Scand J Pain. 2016;13:166-72.

13. McKellar G, Morrison E, McEntegart A, Hampson R, Tierney A, Mackle G, et al. A pilot study of a Mediterranean-type diet intervention in female patients with rheumatoid arthritis living in areas of social deprivation in Glasgow. Ann Rheum Dis. 2007;66(9):1239-43.

14. Messier SP, Loeser RF, Miller GD, Morgan TM, Rejeski WJ, Sevick MA, et al. Exercise and dietary weight loss in overweight and obese older adults with knee osteoarthritis: the arthritis, diet, and activity promotion trial. Arthritis Rheum. 2004;50(5):1501-10.

15. Messier SP, Mihalko SL, Legault C, Miller GD, Nicklas BJ, DeVita P, et al. Effects of intensive diet and exercise on knee joint loads, inflammation, and clinical outcomes among overweight and obese adults with knee osteoarthritis: the IDEA randomized clinical trial. JAMA J Am Med Assoc. 2013;310(12):1263-73.

16. Riecke BF, Christensen R, Christensen P, Leeds AR, Boesen M, Lohmander LS, et al. Comparing two low-energy diets for the treatment of knee osteoarthritis symptoms in obese patients: a pragmatic randomized clinical trial. Osteoarthr Cartil. 2010;18(6):746-54.

17. Rodrigo L, Blanco I, Bobes J, de Serres FJ. Clinical impact of a gluten-free diet on health-related quality of life in seven fibromyalgia syndrome patients with associated celiac disease. BMC Gastroenterol. 2013;13(1):157.

18. Runhaar J, Beavers DP, Miller GD, Nicklas BJ, Loeser $\mathrm{RF}$, Bierma-Zeinstra $\mathrm{S}$, et al. Inflammatory cytokines mediate the effects of diet and exercise on pain and function in knee osteoarthritis independent of BMI. Osteoarthr Cartil. 2019;27(8):1118-23.

19. Strath LJ, Jones CD, Philip George A, Lukens SL, Morrison SA, Soleymani T, et al. The effect of lowcarbohydrate and low-fat diets on pain in individuals with knee osteoarthritis. Pain Med. 2019;21: 150-60.

20. Veronese N, Stubbs B, Noale M, Solmi M, Luchini C, Maggi S. Adherence to the Mediterranean diet is associated with better quality of life: data from the Osteoarthritis Initiative. Am J Clin Nutr. 2016;104(5):1403-9.

21. Lund Haheim L, Nafstad P, Olsen I, Schwarze P, Ronningen KS. C-reactive protein variations for different chronic somatic disorders. Scand J Publ Health. 2009;37(6):640-6.

22. Uceyler N, Eberle T, Rolke R, Birklein F, Sommer C. Differential expression patterns of cytokines in complex regional pain syndrome. Pain. 2007;132(1-2):195-205.

23. Uceyler N, Rogausch JP, Toyka KV, Sommer C. Differential expression of cytokines in painful and painless neuropathies. Neurology. 2007;69(1):42-9.

24. Merlin JS, Westfall AO, Heath SL, Goodin BR, Stewart JC, Sorge RE, et al. Brief report: IL-1beta levels are associated with chronic multisite pain in people living with HIV. J Acquir Immune Defic Syndr. 2017;75(4):e99-e103.

25. Rannou F, Ouanes W, Boutron I, Lovisi B, Fayad F, Mace $Y$, et al. High-sensitivity C-reactive protein in chronic low back pain with vertebral end-plate Modic signal changes. Arthritis Rheum. 2007;57(7): 1311-5.

26. Sandireddy R, Yerra VG, Areti A, Komirishetty P, Kumar A. Neuroinflammation and oxidative stress in diabetic neuropathy: futuristic strategies based on these targets. Int J Endocrinol. 2014;2014: 674987.

27. Schinkel C, Scherens A, Koller M, Roellecke G, Muhr G, Maier C. Systemic inflammatory mediators in post-traumatic complex regional pain syndrome (CRPS I)-longitudinal investigations and differences to control groups. Eur J Med Res. 2009;14(3): 130-5.

28. Sibille KT, Steingrimsdottir OA, Fillingim RB, Stubhaug $A$, Schirmer $H$, Chen $H$, et al. Investigating the burden of chronic pain: an inflammatory and metabolic composite. Pain Res Manag. 2016;2016: 7657329. 
29. Richard C, Couture P, Desroches S, Lamarche B. Effect of the Mediterranean diet with and without weight loss on markers of inflammation in men with metabolic syndrome. Obesity. 2013;21(1): $51-7$.

30. Allison DJ, Thomas A, Beaudry K, Ditor DS. Targeting inflammation as a treatment modality for neuropathic pain in spinal cord injury: a randomized clinical trial. J Neuroinflamm. 2016;13(1):152.

31. Goodin BR, Quinn NB, Kronfli T, King CD, Page GG, Haythornthwaite JA, et al. Experimental pain ratings and reactivity of cortisol and soluble tumor necrosis factor-alpha receptor II following a trial of hypnosis: results of a randomized controlled pilot study. Pain Med. 2012;13(1):29-44.

32. Gregersen S, Samocha-Bonet D, Heilbronn LK, Campbell LV. Inflammatory and oxidative stress responses to high-carbohydrate and high-fat meals in healthy humans. J Nutr Metab. 2012;2012: 238056.

33. Levitan EB, Cook NR, Stampfer MJ, Ridker PM, Rexrode KM, Buring JE, et al. Dietary glycemic index, dietary glycemic load, blood lipids, and C-reactive protein. Metab Clin Exp. 2008;57(3): 437-43.

34. Guo TZ, Wei T, Huang TT, Kingery WS, Clark JD. Oxidative stress contributes to fracture/cast-induced inflammation and pain in a rat model of complex regional pain syndrome. J Pain Off J Am Pain Soc. 2018;19(10):1147-56.

35. Hussain SP, Hofseth LJ, Harris CC. Radical causes of cancer. Nat Rev Cancer. 2003;3(4):276-85.

36. Zou D, Li J, Fan Q, Zheng X, Deng J, Wang S. Reactive oxygen and nitrogen species induce cell apoptosis via a mitochondria-dependent pathway in hyperoxia lung injury. J Cell Biochem. 2018;120: $4837-50$

37. Maritim AC, Sanders RA, Watkins JB 3rd. Diabetes, oxidative stress, and antioxidants: a review. J Biochem Mol Toxicol. 2003;17(1):24-38.

38. Fridovich I. The biology of oxygen radicals. Science. 1978;201(4359):875-80.

39. Manso C. Oxygen radicals in biology. Acta Med Port. 1984;5(3):103-7.

40. Goossens V, De Vos K, Vercammen D, Steemans M, Vancompernolle $\mathrm{K}$, Fiers $\mathrm{W}$, et al. Redox regulation of TNF signaling. BioFactors. 1999;10(2-3):145-56.

41. Jabs T. Reactive oxygen intermediates as mediators of programmed cell death in plants and animals. Biochem Pharmacol. 1999;57(3):231-45.
42. Thornalley PJ. The enzymatic defence against glycation in health, disease and therapeutics: a symposium to examine the concept. Biochem Soc Trans. 2003;31(Pt 6):1341-2.

43. Conner JR, Beisswenger PJ, Szwergold BS. Some clues as to the regulation, expression, function, and distribution of fructosamine-3-kinase and fructosamine-3-kinase-related protein. Ann N Y Acad Sci. 2005;1043:824-36.

44. Conner JR, Beisswenger PJ, Szwergold BS. The expression of the genes for fructosamine-3-kinase and fructosamine-3-kinase-related protein appears to be constitutive and unaffected by environmental signals. Biochem Biophys Res Commun. 2004;323(3):932-6.

45. Baykal T, Seferoglu B, Karsan O, Kiziltunc A, Senel K. Antioxidant profile in patients with complex regional pain syndrome type I. Int J Rheum Dis. 2014;17(2):156-8.

46. Eisenberg E, Shtahl S, Geller R, Reznick AZ, Sharf O, Ravbinovich $\mathrm{M}$, et al. Serum and salivary oxidative analysis in complex regional pain syndrome. Pain. 2008;138(1):226-32.

47. Meeus M, Nijs J, Hermans L, Goubert D, Calders P. The role of mitochondrial dysfunctions due to oxidative and nitrosative stress in the chronic pain or chronic fatigue syndromes and fibromyalgia patients: peripheral and central mechanisms as therapeutic targets? Expert Opin Ther Targets. 2013;17(9):1081-9.

48. Zhao X, Li XL, Liu X, Wang C, Zhou DS, Ma Q, et al. Antinociceptive effects of fisetin against diabetic neuropathic pain in mice: engagement of antioxidant mechanisms and spinal GABAA receptors. Pharmacol Res Off J Ital Pharmacol Soc. 2015;102: 286-97.

49. DeLeo JA, Yezierski RP. The role of neuroinflammation and neuroimmune activation in persistent pain. Pain. 2001;90(1-2):1-6.

50. Watkins LR, Maier SF, Goehler LE. Immune activation: the role of pro-inflammatory cytokines in inflammation, illness responses and pathological pain states. Pain. 1995;63(3):289-302.

51. Feairheller DL, Park JY, Sturgeon KM, Williamson ST, Diaz KM, Veerabhadrappa P, et al. Racial differences in oxidative stress and inflammation: in vitro and in vivo. Clin Transl Sci. 2011;4(1):32-7.

52. Reuter S, Gupta SC, Chaturvedi MM, Aggarwal BB. Oxidative stress, inflammation, and cancer: how are they linked? Free Radic Biol Med. 2010;49(11): 1603-16. 
53. Newsholme P, Cruzat VF, Keane KN, Carlessi R, de Bittencourt PI, Jr. Molecular mechanisms of ROS production and oxidative stress in diabetes. Biochem J. 2016;473(24):4527-50.

54. Totsch SK, Quinn TL, Strath LJ, McMeekin LJ, Cowell RM, Gower BA, et al. The impact of the standard American diet in rats: effects on behavior, physiology and recovery from inflammatory injury. Scand J Pain. 2017;17:316-24.

55. Totsch SK, Meir RY, Quinn TL, Lopez SA, Gower BA, Sorge RE. Effects of a standard American diet and an anti-inflammatory diet in male and female mice. Eur J Pain. 2018;22:1203-13.

56. Chan R, Li S, Choi S, Wang E, Leung J, Benzie I, Sea $\mathrm{M}$, Woo J. Effect of four different meal types on postprandial oxidative stress: a randomized crossover study with healthy subjects. Int J Food Nutr Sci. 2016;3(2):320-30.

57. Ursini F, Zamburlini A, Cazzolato G, Maiorino M, Bon GB, Sevanian A. Postprandial plasma lipid hydroperoxides: a possible link between diet and atherosclerosis. Free Radic Biol Med. 1998;25(2): 250-2.

58. O'Keefe JH, Bell DS. Postprandial hyperglycemia/ hyperlipidemia (postprandial dysmetabolism) is a cardiovascular risk factor. Am J Cardiol. 2007;100(5):899-904.

59. Devaraj S, Wang-Polagruto J, Polagruto J, Keen CL, Jialal I. High-fat, energy-dense, fast-food-style breakfast results in an increase in oxidative stress in metabolic syndrome. Metab Clin Exp. 2008;57(6): 867-70.

60. Tushuizen ME, Nieuwland R, Scheffer PG, Sturk A, Heine RJ, Diamant M. Two consecutive high-fat meals affect endothelial-dependent vasodilation, oxidative stress and cellular microparticles in healthy men. J Thromb Haemost. 2006;4(5):1003-100.

61. Jiang ZY, Woollard AC, Wolff SP. Hydrogen peroxide production during experimental protein glycation. FEBS Lett. 1990;268(1):69-71.

62. Wolff SP, Dean RT. Glucose autoxidation and protein modification. The potential role of 'autoxidative glycosylation' in diabetes. Biochem J. 1987;245(1):243-50.

63. Harding JJ, Beswick HT. The possible contribution of glucose autoxidation to protein modification of diabetes. Biochem J. 1988;249(2):617-8.

64. Halliwell B, Gutteridge JM. Role of free radicals and catalytic metal ions in human disease: an overview. Methods Enzymol. 1990;186:1-85.
65. Hogg N, Kalyanaraman B, Joseph J, Struck A, Parthasarathy S. Inhibition of low-density lipoprotein oxidation by nitric oxide. Potential role in atherogenesis. FEBS Lett. 1993;334(2):170-4.

66. Rubbo H, Parthasarathy S, Barnes S, Kirk M, Kalyanaraman B, Freeman BA. Nitric oxide inhibition of lipoxygenase-dependent liposome and low-density lipoprotein oxidation: termination of radical chain propagation reactions and formation of nitrogencontaining oxidized lipid derivatives. Arch Biochem Biophys. 1995;324(1):15-25.

67. Tsai EC, Hirsch IB, Brunzell JD, Chait A. Reduced plasma peroxyl radical trapping capacity and increased susceptibility of LDL to oxidation in poorly controlled IDDM. Diabetes. 1994;43(8): 1010-4.

68. Kawamura M, Heinecke JW, Chait A. Pathophysiological concentrations of glucose promote oxidative modification of low density lipoprotein by a superoxide-dependent pathway. J Clin Investig. 1994;94(2):771-8.

69. Gkogkolou P, Bohm M. Advanced glycation end products: key players in skin aging? Dermatoendocrinol. 2012;4(3):259-70.

70. Goldin A, Beckman JA, Schmidt AM, Creager MA. Advanced glycation end products: sparking the development of diabetic vascular injury. Circulation. 2006;114(6):597-605.

71. Hori O, Yan SD, Ogawa S, Kuwabara K, Matsumoto $\mathrm{M}$, Stern $\mathrm{D}$, et al. The receptor for advanced glycation end-products has a central role in mediating the effects of advanced glycation end-products on the development of vascular disease in diabetes mellitus. Nephrol Dial Transpl. 1996;11(Suppl 5): 13-6.

72. Mullarkey CJ, Edelstein D, Brownlee M. Free radical generation by early glycation products: a mechanism for accelerated atherogenesis in diabetes. Biochem Biophys Res Commun. 1990;173(3): 932-9.

73. Bayir H, Kagan VE. Bench-to-bedside review: Mitochondrial injury, oxidative stress and apoptosis-there is nothing more practical than a good theory. Crit Care. 2008;12(1):206.

74. Mittal M, Siddiqui MR, Tran K, Reddy SP, Malik AB. Reactive oxygen species in inflammation and tissue injury. Antioxid Redox Signal. 2017;20(7):1126-67.

75. Carlsen MH, Halvorsen BL, Holte K, Bøhn SK, Dragland S, Sampson L, et al. The total antioxidant content of more than 3100 foods, beverages, spices, herbs and supplements used worldwide. Nutr J. 2010;9:3. 
76. Frei B, England L, Ames BN. Ascorbate is an outstanding antioxidant in human blood plasma. Proc Natl Acad Sci USA. 1989;86(16):6377-81.

77. Institute of Medicine Panel on Dietary A, Related C. Dietary reference intakes for vitamin C, Vitamin E, selenium, and carotenoids. Washington: National Academies Press; 2000 (Copyright 2000 by the National Academy of Sciences. All rights reserved).

78. Halliwell B. The antioxidant vitamins $\mathrm{C}$ and E: Packer L, Traber MG, Kramer K and Frei B. (Eds.) AOCS Press, Champaign, Illinois, 2002. Free Radic Res. 2003;37(10):1146

79. Frei B. Efficacy of dietary antioxidants to prevent oxidative damage and inhibit chronic disease. J Nutr. 3196S;134(11):3196S-S31983198.

80. Annuzzi G, Bozzetto L, Costabile G, Giacco R, Mangione A, Anniballi G, et al. Diets naturally rich in polyphenols improve fasting and postprandial dyslipidemia and reduce oxidative stress: a randomized controlled trial. Am J Clin Nutr. 2013;99(3):463-71.

81. Dewell A, Tsao P, Rigdon J, Gardner CD. Antioxidants from diet or supplements do not alter inflammatory markers in adults with cardiovascular disease risk. A pilot randomized controlled trial. Nutr Res New York NY. 2018;50:63-72.

82. Kitabchi AE, McDaniel KA, Wan JY, Tylavsky FA, Jacovino CA, Sands CW, et al. Effects of high-protein versus high-carbohydrate diets on markers of beta-cell function, oxidative stress, lipid peroxidation, proinflammatory cytokines, and adipokines in obese, premenopausal women without diabetes: a randomized controlled trial. Diabetes Care. 2013;36(7):1919-25.

83. Sanchez-Sanchez ML, Garcia-Vigara A, HidalgoMora JJ, Garcia-Perez MA, Tarin J, Cano A. Mediterranean diet and health: a systematic review of epidemiological studies and intervention trials. Maturitas. 2020;136:25-37.

84. Wermers J. Mediterranean-style diet for the primary and secondary prevention of cardiovascular disease: summary of a Cochrane review. Explore (NY). 2020;16(3):201-2.

85. Davis C, Bryan J, Hodgson J, Murphy K. Definition of the Mediterranean diet; a literature review. Nutrients. 2015;7(11):9139-53.

86. 2015-2020 Dietary Guidelines for Americans. 8th Edition ed2015

87. Casas R, Sacanella E, Urpi-Sarda M, Chiva-Blanch G, Ros E, Martinez-Gonzalez MA, et al. The effects of the Mediterranean diet on biomarkers of vascular wall inflammation and plaque vulnerability in subjects with high risk for cardiovascular disease. A randomized trial. PLoS ONE. 2014;9(6):e100084.

88. Camargo A, Delgado-Lista J, Garcia-Rios A, CruzTeno C, Yubero-Serrano EM, Perez-Martinez P, et al. Expression of proinflammatory, proatherogenic genes is reduced by the Mediterranean diet in elderly people. Br J Nutr. 2012;108(3):500-8.

89. Konstantinidou V, Covas MI, Munoz-Aguayo D, Khymenets O, de la Torre R, Saez G, et al. In vivo nutrigenomic effects of virgin olive oil polyphenols within the frame of the Mediterranean diet: a randomized controlled trial. FASEB J Off Pub Fed Am Soc Exp Biol. 2010;24(7):2546-57.

90. Green CR, Anderson KO, Baker TA, Campbell LC, Decker S, Fillingim RB, et al. The unequal burden of pain: confronting racial and ethnic disparities in pain. Pain Med. 2003;4(3):277-94.

91. Williams DR, Mohammed SA, Leavell J, Collins C. Race, socioeconomic status, and health: complexities, ongoing challenges, and research opportunities. Ann N Y Acad Sci. 2010;1186:69-101.

92. Darmon N, Drewnowski A. Does social class predict diet quality? Am J Clin Nutr. 2008;87(5):1107-17.

93. Lopez CN, Martinez-Gonzalez MA, Sanchez-Villegas A, Alonso A, Pimenta AM, Bes-Rastrollo M. Costs of Mediterranean and western dietary patterns in a Spanish cohort and their relationship with prospective weight change. J Epidemiol Comm Health. 2009;63(11):920-7.

94. Tong TYN, Imamura F, Monsivais P, Brage S, Griffin SJ, Wareham NJ, et al. Dietary cost associated with adherence to the Mediterranean diet, and its variation by socio-economic factors in the UK Fenland Study. Br J Nutr. 2018;119(6):685-94.

95. Saulle R, Semyonov L, La Torre G. Cost and costeffectiveness of the Mediterranean diet: results of a systematic review. Nutrients. 2013;5(11):4566-86.

96. Brouwer-Brolsma EM, Dhonukshe-Rutten RA, van Wijngaarden JP, Zwaluw NL, Velde N, de Groot LC. Dietary sources of vitamin B-12 and their association with vitamin B-12 status markers in healthy older adults in the B-PROOF study. Nutrients. 2015;7(9):7781-97.

97. Guo J, Lovegrove JA, Givens DI. A narrative review of the role of foods as dietary sources of vitamin d of ethnic minority populations with darker skin: the underestimated challenge. Nutrients. 2019;11(1):81. 